ceived. The relation is, on one side, escentially cognitive, but it indicates the ciroumstantial spatial relations of actual contact with, or direction of the oyee towards, the object. These relations may be observed to subaist when two persons ahske hands or take hold of the same rope, or when one person another looking st the same object which has sttracted his own attention.

Charles E. Hoopre.

\title{
ANGLO-AMERICAN UNIVERSITY LIBRARY FOR CENTRAL EUROPE
}

\section{Lordox SCHOOL or EOONOBnCs,}

Clabe Mabeet, W.C. 2.

1st Februaly, 1921.

To THE Editor or "MIND".

SIR,

In connexion with the above Library, we are endenvouring to supply the various university libraries on the Continent with the scientific journals they urgently need.

Among the periodicals for which we have received a pressing demand Mns is frequently mentioned, and I very much hope that you will be good enough to publish this letter in your columns, so that any of your readers having copies of your journal from 1914 onwards may hear of our appeal. Any numbers of the periodical which readers msy foel they can diapense with, will be most gratefully welcomed.

The Library is entirely non-political and non-sectarian, its sole object being to enable humanity at large to benefit in the future, as it has done in the past, from the research of European scholars. Such research has been brought almost to a standytill from the fact that European centres of learning have been cut off since 1914, first of all by the blockade and more recently by the excedingly unfavourable position of the foreign erchangeg, from Engliah and American thought.

I fervently hope that some of your readers may be able to help in supplying the literary needs of Central Europe. A copy of the prospectus of the Library will gladly be sent to anyone desiring a fuller accuunt of its work and objocts.

$$
\begin{aligned}
& \text { I \&m, Sir, } \\
& \text { Yours very truly, } \\
& \text { B. M. Headicar. } \\
& \text { Hon. Becretary. }
\end{aligned}
$$

\section{INVITATION FROM THE SOCIÉTÉ: FRANGAISE DE PHILOSOPHIE.}

Monsifur Xavier Léon, President of the Société Française de Philosophio, has ment the following letter to Professor Wildon Carr, Honorary Secretary of the Aristotelian Society (107 Church Street, Chelsen S.W. 3), as representing the English Societies which took part in the Congreas of Philosophy at Oxford in September, 1920.

Cher Mongieuk Wildox Care,

$$
\text { Pariv, le } 28 \text { Février, } 1921 .
$$

J'ai le plaisir de vous informer que, dans sa réunion du 24 Février, la Société frauçaise de philosophie a décidé adresser uux Sociétés anglaises de 